\title{
On MNC-Host Government Relations: How Finnish Firms Respond to National and Regional Policies in ASEAN
}

\author{
ERJA KETTUNEN
}

\begin{abstract}
Combining literature from international political economy, international business, and institutional approaches to business studies, this article discusses foreign firms' relationship with the public sector in Southeast Asia. It focuses on the perceptions of the firms on host country policies toward foreign direct investments (FDI) and the impact of global financial crises and regional economic integration on the firms' strategies. The multinational company (MNC)-host government relationship is seen as a cooperative and continual bargaining within a specific institutional framework. Based on interviews with managers of subsidiaries originating from Finland, it is found that the regulatory environment of Association of Southeast Asian Nations (ASEAN) countries varies from easy to difficult with regard to policies, bureaucracy and protectionism. These pose institutional constraints for the firms, with additional economic constraints caused by global financial crises. Contrary to expectations, the ASEAN free trade agreement does not figure in the firms' investment strategies. This is explained by three findings: most of the firms serve the domestic host country market; the firms operate global rather than ASEAN-wide regional production chains; the firms represent industries that are not typical in Southeast Asian regional production networks.
\end{abstract}

Keywords: MNC, host country, bargaining, institutions, ASEAN

\section{Introduction}

This article discusses the relationship between foreign firms and the public sector in Southeast Asia. ${ }^{1}$ Of particular interest are the companies' views on the national and regional policies of the host governments toward foreign-invested firms. The region, consisting of member countries of the Association of Southeast Asian Nations (ASEAN), has been a favourable investment target for foreign firms for several decades. Aside from periods of downturn, such as the 1997 Asian financial crisis or the 2008 global financial crisis, many ASEAN countries have experienced long-term economic growth based on inward foreign direct investments 
(FDI). Several of them, such as Singapore and Malaysia, have been open for FDI in an export-oriented industrialization strategy. Multinational companies (MNC) have invested in these economies, often to create regional production chains: importing raw materials from one country for processing in a second country, and exporting intermediate goods or final products to a third country. The result has been a rapid growth in foreign trade in the region (see Athukorala 2007, Coxhead 2015, Gugler and Chaisse 2010, Kuroiwa and Kumagai 2011, Kuroiwa and Toh 2008). This has been concurrent with the gradual regional economic integration process, i.e. the ASEAN Free Trade Area (AFTA) and the recently agreed ASEAN Economic Community (AEC), both of which are bound to liberalize trade in the region and thus contribute to the development of regional value chains (ASEAN 2014, Kawai 2016).

The openness of these economies for FDI and foreign trade varies, however, and their general business environment may be challenging for foreign investors in times of economic downturn. In contrast, the process of regional integration may enhance the potential for inward foreign investments. Both developments are visible in the ASEAN region: the global financial crisis resulted in negative GDP growth in 2009 in Malaysia, Thailand and Singapore, and a recovery in 2010 (World Bank 2016). ${ }^{2}$ Since then, growth has stabilized, and renewed efforts at regional economic integration have taken a step forward with the launch of the AEC in late 2015 (ASEAN 2015, Basu Das 2012) ${ }^{3}$. This study, therefore, aims to shed light on the investment climate in Southeast Asia after the 2008 global financial crisis by discussing the experiences of foreign firms in ASEAN economies, particularly Singapore, Malaysia, Thailand and Indonesia. To do this, a conceptual framework is combined from studies in international political economy, international business, and the institutional approach to business studies. The focus is on two questions:

1) How do foreign firms perceive the host country's policies toward foreign investors after the global financial crisis?

2) What is the impact of ASEAN economic integration, particularly AFTA, on the firms' investment decisions?

The empirical data is drawn from interviews with managers of Finnish companies operating in ASEAN countries. It is assumed that these and MNCs from other countries encounter a similar business environment. In addition to well-known examples such as Nokia in telecom, or Kone, one of the world's largest elevator manufacturers, a number of Finnish firms have had a long history of operating in the region. It is anticipated 
that financial crises have an immediate impact on business environments (e.g. Kee et al. 2013, Makkonen et al. 2014), often leading to more protectionist policies, and that regional economic integration has the opposite effect. This study adopts the perspective of the companies and focuses on their responses to the regulatory environment. The hypothesis is that the firms and host states are increasingly interdependent, and that both need to adapt to changing international macroeconomic contexts. It is argued that national-level host country policies have a stronger impact on the firms' strategies than regional ones (e.g. free trade areas), and explanations are given as to why AFTA does not figure in the selected firms' investment decisions.

To elaborate on the MNC-host government relationships, the study adopts a qualitative approach to analyze and triangulate two types of data. Primary data is retrieved from 18 semi-structured interviews carried out at the subsidiaries of Finnish firms and support organizations in the ASEAN region, primarily in Malaysia and Singapore. Most of the interviews (15) were conducted in the aftermath of the global financial crisis in 2009-2011, and further three took place in 2014-2015. Secondary data were drawn from the World Bank's Doing Business reports, which assess changes in the regulatory environment across the world's economies. The article is presented in four sections. It opens with a statement of the conceptual framework and multidisciplinary approach; this is followed by discussion of the findings on the firms' responses to national and regional policies. The article concludes with the implications for research on bargaining relationships and institutional constraints, as well as the business response to free trade areas.

\section{Conceptual Framework on Firm-State Relationships: Bargaining Relationships between MNCs and Host Governments}

The relationship between MNCs and host country governments has generally been theorized in the international political economy and international business literature as a bargaining relationship. Susan Strange, one of the early theorists of international political economy, discussed the changing relationships between states and markets, and argued that these were determined by the power relationships between the two (Strange 1988). For example, foreign trade is an outcome not only of supply and demand, but also of complex networks of economic and political bargains between states and firms (Strange 1988: 161). 
Similarly, Stopford et al. (1991) elaborated on the bargaining relationship between a developing country and a multinational firm in relation to foreign direct investment, distinguishing between various types of competitive structures of the firm and policy intents of the host states. They focused on trade policies, since export creation is one of the key policy needs for developing countries and firms often aim to export from their production bases in developing countries. This is particularly true for Southeast Asia, where MNCs typically create regional production chains involving cross-border imports and exports (see Kuroiwa and Kumagai 2011).

Similarly, the international business literature views the relationship between foreign firm and host country government as a bargaining negotiation where both parties possess specific resources desired by the other. Notably, Kobrin (1987: 619-622) elaborated on the bargaining between a manufacturing multinational and a developing country government over the terms of an investment, and concluded that the MNC's power resources include technology, managerial skills, capital, access to markets and export potential, whereas the host country's power resources comprise access to the host market, control of natural resources, availability of inexpensive and productive labour, and government incentives. These also reflect the MNCs' investment motives (Dunning 1998), such as seeking markets, resources, efficiency or strategic assets by engaging in FDI.

Empirical research indicated that the firm initially had a stronger position in the bargaining process, but that this relative power would obsolesce and shift to the host country government, wherein the firm's assets were 'transformed into hostages' e.g. through nationalization (Eden et al. 2005: 253). This was labelled the obsolescing bargain model (OBM) developed by Vernon (1971, 1977), Kobrin (1987) and Grosse and Behrman (1992). The OBM explained the changing nature of bargaining relationships between a MNC and a host country government as a function of goals, resources and constraints on both parties. The dynamic was considered to be confrontational, particularly during the 1970s, as it was typically situated in the context of MNC investments in extractive industries in developing countries.

International business research now widely regards OBM as outmoded, and instead favours models drawn from institutional theory (Grosse 2005: 4). For example, Eden et al. (2005) criticize the deficiencies of the OBM and instead develop a 'political bargaining model' where the bargain is seen as cooperative and iterative, with recurrent negotia- 
tions taking place between the MNC and the host country. The bargain is not only about the initial entry of the firm, but on a wide variety of government policies over time, typically at the industry level. Embracing insights from research on the liability of foreignness, transaction cost economics and the resource-based approach, the authors argue that, in addition to economic and political constraints, the bargain is affected by institutional constraints (Eden et al. 2005: 270). For example, governments must take into account other stakeholders, such as consumers and non-governmental organizations, as well as commitments, such as memberships in regional accords or international organizations. Firms may bargain either individually or they may lobby as a group, and the network may also include domestic firms.

Certainly, this is a better reflection of the reality in the current context where MNCs negotiate with host governments at various levels and often on a cooperative basis. The interactions may consist of, for example, meetings between firms and local officials regarding various application procedures (certificates, standards, etc.) and related legislation, or bringing forth business interests to the policymakers in joint seminars. A recent study found that one of the main motives for MNCs to establish relationships with host governments included information exchange and communication, as well as the promotion of business interests (Wagner 2013). These types of interactions typically require personal contacts with the authorities. Also, as Meyer (2004) notes, policymakers in emerging economies have to consider how foreign investments contribute to national welfare, acknowledging the likely positive and negative influences of FDI to local firms and people. It is seen that globalization has increased mutual interdependence between host states and foreign firms (Luo 2001) and, in some cases, states may even become 'hostages' of powerful multinational corporations.

\section{Business Response to Free Trade Areas}

For MNCs, regional trade groupings are an important consideration. The host state may be active in regional trade agreements, aiming to attract inward FDI by providing better access to regional markets. From the perspective of a company, locating in a country that belongs to a regional grouping, such as a free trade area (FTA), is a good option since it will enable exports and imports at a lower cost. In Southeast Asia, formal regional economic integration has progressed by means of the ASEAN Free Trade Area, which was signed in 1992 and 'virtually established' in 2005 (ASEAN 2004) ${ }^{4}$, as well as the ASEAN Economic Community, 
originally declared in 2003 and launched in 2015 (Hew 2007, Lee 2011). However, compared to Europe or North America, state-led integration in Southeast Asia is still in the formative stages, and the surge of Asian regional trade agreements is a relatively new phenomenon (Kawai and Wignaraja 2008, UNCTAD-JETRO 2008).

Indeed, Southeast Asia has a history of business-driven integration through companies' regional production chains. Empirical evidence showed a locational specialization between stages of production in Southeast Asia in the 1980s, when the region had become a production platform for American and Japanese manufacturers (Alvstam et al. 2014, Kuroiwa and Toh 2008, WTO 2011, Teh 2015). In regional production chains, raw materials for processing were imported to a host country, such as Malaysia, where processing involved either one or several stages of production, and intermediate goods were exported for further processing to third countries. This was enabled by agglomeration, the development of industrial clusters that had good logistical connections with other industrial clusters in the region (Nishikimi and Kuroiwa 2011: 51). However, as Fujita et al. (2011) point out, formal integration has gained momentum in Southeast Asia, particularly since the launch of AFTA.

The impact of Asian FTAs on firm behaviour was under-researched until the last few years. This gap has recently been filled by Masahiro Kawai and Ganeshan Wignaraja, particularly through their research on business responses to free trade areas. Extensive surveys were conducted in exporting firms in China, Japan, Korea, Singapore, Thailand and the Philippines in 2007-2008 to investigate whether the firms used the tariff preferences offered by free trade agreements. Quite surprisingly, relatively few firms actually do use, or benefit from, the Asian FTAs (Kawai and Wignaraja 2009, 2011a, 2011b, 2013). Of the 841 firms studied, only 28 per cent did so; the main impediments to using the FTA preferences were identified as lack of information, small preference margins, delays and administrative costs associated with the needed bureaucratic procedures, and non-tariff measures in trade partner countries (Kawai and Wignaraja 2011a: 39). In other words, the firms either did not know about the possibility of lower tariffs, or they perceived the costs arising from the bureaucracy as being too high.

In an additional round of surveys in 2011-2012 in the same six countries plus Malaysia, 32 per cent of the 1075 firms were using the FTA preferences (Kawai and Wignaraja 2013: 20). This was the average for all seven countries; the figures were even smaller in the case of ASEAN 
countries: Indonesia (30 per cent), Malaysia (27 per cent), Thailand (25 per cent), the Philippines (20 per cent) and Singapore (17 per cent) (Kawai and Wignaraja 2013, Wignaraja 2013). It was found that larger firms used the preferences more often than smaller firms. This was explained by the significant fixed costs related to learning about FTA provisions in the first place, the challenges of tailoring business plans to fit the complex tariff schedules, and difficulties in obtaining certificates of origin, which are hard to bear for a small firm (Kawai and Wignaraja 2013: 21-22). Similar results have been obtained from European firms that operate in ASEAN countries. In a recent survey by the EU-ASEAN Business Council (the first of its kind) only 26 per cent of the 151 respondents used the so-called ASEAN +1 free trade agreements in their exports of goods to FTA partners (Australia, China, India, Japan, New Zealand and South Korea) (EU-ABC 2015: 24). The main reason seems to be the uncertainty among firms of the potential benefits of the FTAs for their business.

\section{Institutional Framework for MNC-Host Government Relationships}

The literature discussed above forms the backdrop for an empirical analysis of the foreign firms' views on national and regional policies in ASEAN. The framework for analyzing the bargaining relationship between multinational companies and host country governments is presented below (Figure 1). It is understood that bargaining mainly takes place over the policies of the host country regarding the firm's investment, is continual, and is affected by institutional and economic constraints. From the perspective of a firm, this constitutes the framework that it needs to adapt to in the particular business environment.

The institutional approach to business studies maintains that the MNCs' strategic choices are driven not only by their resources, capacities and industrial dynamics, but also by the particular institutional constraints that decision-makers face in the business environment (Peng 2003). Particularly in emerging economies, institutions have a strong impact on the performance of firms (Peng et al. 2008). The institutional framework of a nation is defined by North (1990: 3) as 'the rules of the game in a society' including both formal institutions (e.g. laws, regulations and contracts) and informal institutions (e.g. norms, cultures and practices). Formal institutions are defined as codified and explicit rules, while informal institutions are shared meanings and collective understandings (Holmes et al. 2013: 533). For example, the tariff regime 
FIGURE 1. Bargaining Relationship Between MNC and Host Country Government

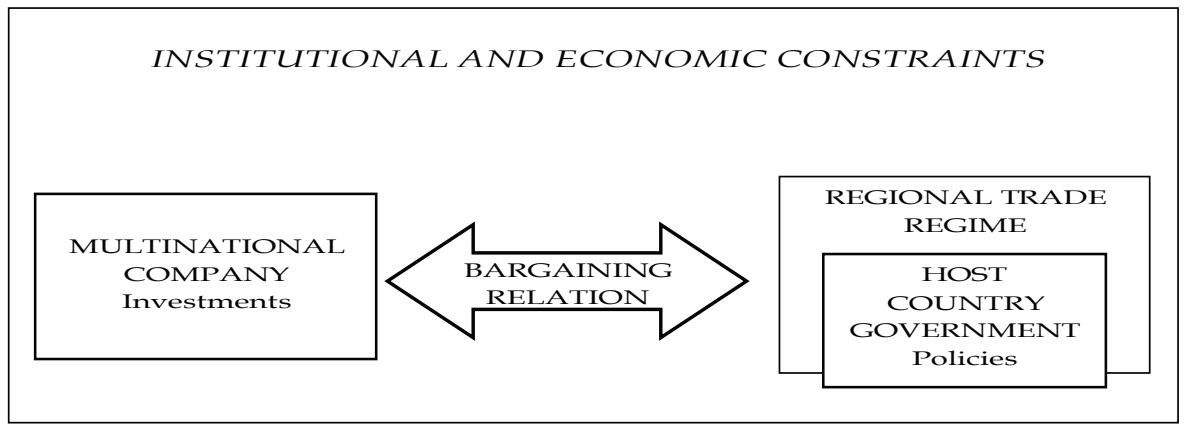

Source: Author' s elaboration.

of a host state is part of the formal institutional framework, whereas the practices of the authorities are informal institutions that may affect the firm more than the formal legislation itself, particularly in developing and transitional economies. Formal and informal institutions may also contradict each other, such as when the law is misinterpreted by authorities.

Further, macroeconomic and financial crises pose economic constraints for host countries, e.g. by way of balance of payments difficulties (Eden et al. 2005). In this way, economic constraints can inhibit the bargaining relationship (see Figure 1). The remainder of the article presents the research findings by discussing the main concepts in this framework to the extent that they were considered relevant by the interviewees.

\section{Bargaining on National and Regional Policies in ASEAN Countries}

Most of the firms interviewed have relatively extensive experience of operating in Southeast Asia; ten of the subsidiaries had been established during the 1980s-1990s, and three in the 2000s. The firms represent the main Finnish industries in the region: four are in electronics or information technology, four in forest-based industries or chemistry, two in engineering, two in other industries, and one in services. Five respondents are from supporting organizations, such as chambers of commerce. Company sizes vary: five are subsidiaries of large enterprises (the parent company having more than 2000 employees), whereas eight are small or medium-sized (see Appendix, Table A1). Many of the firms have units in more than one ASEAN country, mostly in Singapore (nine subsidiaries) and Malaysia (seven), but also in Indonesia (three), 
Thailand (three), the Philippines (one), and Vietnam (one): a total of 24 subsidiaries. ${ }^{5}$ The interviewees were identified from member lists of Finland-ASEAN Trade Association and Finnish Business Councils in Singapore and Malaysia; 32 persons were contacted, of whom 18 agreed to an interview, four declined, and ten did not reply or could not be reached. The respondents were typically general managers of the subsidiaries. The interviews were conducted either as face-to-face discussions or over the telephone, lasted around one hour, and were tape-recorded, transcribed and coded using NVivo software. The semistructured interview has the advantage of guiding the discussion while at the same time allowing the respondents to identify issues related to the questions. Anonymity was guaranteed for the respondents. Quotations from the interviews are given in italics.

The next sections analyze the firms' relationships with host country governments and their views on national and regional policies. Following North's (1990) framework, the analysis elaborates on institutional constraints, i.e. formal and informal institutions that affect the MNC operations (Holmes et al. 2013, Peng 2003). The discussion will focus on 1) the regulatory environment in the ASEAN countries, 2) the impact of the global financial crisis, and 3) the impact of regional economic integration on the firms' strategies and investment decisions.

\section{Regulatory Environment}

In order to gain an overall view of the policy environment in Southeast Asia, Table 1 (below) presents the World Bank's indicators on the ease of doing business in four ASEAN countries where the Finnish firms are mostly located. The indicators measure the regulatory quality and efficiency that either enhance or constrain business activity, and compare these across the world's economies (in 2014, altogether 189 countries), where rank 1 signifies the easiest business environment. The table shows the overall rank and the 'trading across borders' rank in 2008, 2011 and 2015 (before and after the global financial crisis).

As can be seen, the overall ease of doing business remained the same in Singapore after the crisis, worsened in Thailand, and improved in Malaysia and Indonesia. Singapore is in each year the most favourable business environment in the world, being ranked as number one among all countries included in the report. Also in trading across borders, Singapore is the world's easiest place across all three years. In comparison, Malaysia and Thailand are relatively easy business environments, holding overall positions of 15-26 in the studied years. Malaysia has improved 
TABLE 1. Ease of Doing Business Ranks in Four ASEAN Countries in 2008, 2011 and 2015 (out of 178, 183 and 189 countries, respectively).

\begin{tabular}{|l|c|c|c|c|c|c|}
\hline \multirow{2}{*}{} & \multicolumn{3}{|l|}{ Overall rank } & \multicolumn{3}{c|}{ Trading across borders } \\
\cline { 2 - 7 } & 2008 & 2011 & 2015 & 2008 & 2011 & 2015 \\
\hline Singapore & 1 & 1 & 1 & 1 & 1 & 1 \\
\hline Malaysia & 24 & 21 & 18 & 21 & 37 & 11 \\
\hline Thailand & 15 & 19 & 26 & 50 & 12 & 36 \\
\hline Indonesia & 123 & 121 & 114 & 41 & 47 & 62 \\
\hline
\end{tabular}

Source: World Bank (2007; 2010; 2014).

its performance in trading across borders in 2015, while Thailand has experienced the opposite. For Indonesia, the results are clearly poorer, indicating a far more difficult business environment.

The views of the companies align with these indicators. The interviewed firms perceive the more developed ASEAN countries as relatively unproblematic business environments, especially if compared with India or China. However, they also refer to national policies and local practices that hinder business, as well as the impact of the global financial crisis on the policies. These pose constraints on the firms' relationship with the public sector.

Below, Table 2 lists the various types of formal and informal institutional constraints that affect the firms' bargaining relationship with the governments of the host countries. These, alongside the impact of the financial crisis, are shown as expressed by the interviewees. To begin with, Singapore is regarded as the 'easiest place for a firm', an open economy for FDI, where it is easy to set up a company. The Economic Development Board is very efficient, foreign firms are given tax reliefs, and there are no problems whatsoever with the public sector. In addition, Singapore is a safe living and business environment, with no corruption, being 'cleaner than Finland'.

Malaysia is seen as a fairly easy business environment, with 'no big problems'. There are the 'normal license procedures' at the start of the firms' operations. Most of the interviewees refer to 'some bureaucracy', but 'not a regulation jungle'. The Malaysian Industrial Development Authority is viewed as 'positive', professional and easy to deal with. Some respondents mention the requirement to have a local Malay (bumiputra) board member whom they have 'never seen', as well as the need to have a bumiputra partner in large projects. One company was obliged to hire a local official who was responsible for approving applications, to consult in filling and filing its application, which was seen as being 'in the borderline of corruption'. 
There are local technical standards in some sectors that hinder business. However, firms can apply for government grants, particularly in the information technology sector, and several companies have received small tax benefits, tax relief or other advantages, such as easy expat permits, by having the Multimedia Super Corridor status (see Table 2).

The companies' views on Thailand are somewhat more critical. The Thai economy is seen as 'relatively closed' with many protected sectors, particularly when compared with Malaysia. There are burdensome license procedures, 'most strange permits' that firms need to apply, 'payments under the table', and documentation must typically be presented in the local language, which means 'you have to deal with officials all the time'. Expatriates need to renew residence permits every six months, and this red-tape 'makes one feel they don't want foreigners'. Political crises occur frequently in Thailand, though these mainly affect state-related businesses.

TABLE 2. Institutional Constraints Encountered by Firms in Their Relationship with Host Country Governments in Four ASEAN Countries

\begin{tabular}{|l|l|l|l|}
\hline & Formal constraints & Informal constraints & $\begin{array}{l}\text { Impact of the glo- } \\
\text { bal financial crisis }\end{array}$ \\
\hline Singapore & None & None & Not mentioned \\
\hline Malaysia & $\begin{array}{l}\text { Bumiputra policies; } \\
\text { technical standards }\end{array}$ & Bureaucracy & $\begin{array}{l}\text { New trade barri- } \\
\text { ers; stricter work } \\
\text { permits }\end{array}$ \\
\hline Indonesia & $\begin{array}{l}\text { Manifold licenses } \\
\text { and permits; docu- } \\
\text { mentation in thai } \\
\text { language }\end{array}$ & $\begin{array}{l}\text { Heavy bureaucracy; } \\
\text { political crises af- } \\
\text { fecting state-related } \\
\text { business; corruption }\end{array}$ & $\begin{array}{l}\text { New trade barriers; } \\
\text { more difficult im- } \\
\text { migration proce- } \\
\text { dures }\end{array}$ \\
$\begin{array}{l}\text { Changing legisla- } \\
\text { tion; restrictions } \\
\text { on immigration of } \\
\text { expatriates }\end{array}$ & $\begin{array}{l}\text { Changing interpre- } \\
\text { tations of the laws, } \\
\text { inefficiency and } \\
\text { arbitrariness of the } \\
\text { authorities; corrup- } \\
\text { tion }\end{array}$ & New trade barriers \\
\hline
\end{tabular}

Source: interviews.

Similarly, Indonesia is challenging when it comes to firms' relationships with the public sector. The firms encounter frequently changing laws, changing interpretations of the legislation, inefficiency, arbitrariness of the authorities and corruption. Encounters with officials may be difficult; for example, it is hard to know 'whether customs clearance will be fast or will take weeks or months', especially if the authorities are not familiar with the product or 'not very efficient or motivated'. It is hard to 
establish a business and bring expatriates into the country even when the required skills are not available among the local workforce. The business environment is challenging because 'political and economic power is in the same hands'. In some sectors, the application processes for licenses have been shifted from central government to regional authorities, resulting in corruption at the local level (see Table 2).

In sum, the research showed that informal institutions, understood as norms, social codes and everyday practices, can significantly constrain the actions of foreign firms and are highly relevant in an analysis of the bargaining relationship. As an aspect of the local setting which firms must adapt to, these social norms are typically experienced as obscure and unclear practices that foreign managers may find hard to cope with. While prior research suggests that formal institutions affect the initial entry more than informal institutions do (Holmes et al. 2013: 557), informal institutions seem to become a constraint for MNCs after the entry phase, especially in developing countries. Often firms need to build personal contacts within the public sector to overcome these constraints (see Peng 2003). The firm's strategy may be to strengthen its relationships with the host state by interacting with the authorities in order to attain goals in bargaining (Eden et al. 2005: 270). The interviewed firms commented about their communication with the public sector in Singapore and Malaysia, the two easiest host states in terms of regulatory efficiency, where it is less likely for foreign firms to have to nurture personal relationships with the authorities. The need for personal contacts varies according to company size and operation mode: in Singapore, firms that merely operate sales offices do not have to interact too much with the public sector, as everything is 'easy and clear', whereas many of the larger MNCs have direct contacts with a local minister. Similarly in Malaysia, large firms often nurture personto-person connections and do some lobbying, while smaller firms have no need for personal contact with the authorities. Overall, firms that are located in Cyberjaya or the Multimedia Super Corridor have little contact with the public sector.

\section{Impact of the Global Financial Crisis}

The global financial crisis affected host country policies in ways that added additional constraints for the firms. New trade barriers were perceived in Indonesia, Malaysia and Thailand. It was also mentioned that the process of getting work permits became stricter in Malaysia. Similarly, immigration procedures - not the law itself - were tightened 
in Thailand. These posed new institutional constraints for the operations of the firms (Table 2 above), though such constraints could also be lessened by state action (Eden et al. 2005: 270). The global financial crisis prompted some ASEAN governments to support the domestic economy by easing policy requirements, and some measures were taken to reduce the costs of businesses. For example, Malaysia reduced registration fees in 2008 in response to the economic crisis (World Bank 2010: 24), and deregulated several services and financial subsectors in 2009 (Chin 2012: 23). Singapore implemented tax cuts in 2009 to help businesses manage the economic slowdown (World Bank 2010: 54). In spite of these, the firms also commented on negative policy-related impacts of the crisis.

Thus, the bargaining relationship can be inhibited by economic constraints, such as financial crises (Eden et al. 2005). The interviewees regarded the impact of the global financial crisis on the macro economy as relatively mild, especially when compared to the Asian financial crisis of the previous decade (cf. Nidhiprabha 2015). This time, the crisis mostly resulted in a reduction of foreign trade in Southeast Asia. This was especially true for export-oriented economies; Malaysia's foreign trade dropped by 60 per cent in late 2008, and Thailand's by 80 per cent in early 2009 (Risager 2013: 91). Yet the interviewees considered the effect to be greater on the economies of Europe and North America and smaller in Southeast Asia, where growth continued in many industries. For example, Vietnam continued to be a growth market for some of the firms despite slowdown elsewhere. Also China was perceived to suffer more from the crisis, which led to some of the China-based firms to seek new markets in Southeast Asia.

Firm-level effects also varied, as some industries were affected more than others. Depending on the market situation of the firm, the impact of the global financial crisis ranged between 'none' for firms whose business continued to grow, to 'a big effect' for firms whose turnover and profit declined significantly so that 'everything was put on hold' despite prior growth plans and notable investments. Between these extremes, there were firms whose sales stabilized with no growth but 'no big decline either' because of a diversified business, or those whose sales 'dropped a little', resulting in the postponement of certain investment decisions. One reason for the decline in sales was the poor creditworthiness of the customer companies. However, some firms also enjoyed clear benefits accruing from the crisis. Those whose industries had an overheated market and 'too full' order books were particularly pleased, as the crisis 
helped cool down the market. Other benefits included savings in costs. One company was able to 'save a little in the construction costs' for new industrial premises. Two noted that it was easier to hire new personnel and to keep existing employees, as the problem of job-hopping had subsided during the economic crisis.

By 2015, the firms' main concerns included the problems of the national economies, slowly declining growth in China, and ambivalence regarding the forthcoming ASEAN Economic Community. The decline in global oil prices has resulted in macroeconomic challenges for oilexporting countries, notably Malaysia and Indonesia. For example, Malaysia is suffering from 'a currency crisis, increased import prices, and a decline in state revenue'. Inward investments are down: there is 'no crowd' coming to Malaysia. Also Indonesia encounters economic problems due to the decline in oil prices. Because of its lack of competitiveness in non-oil industries in the global market, Indonesia has instead turned inwards to 'protectionism, resorting to the large domestic market and not letting competitors in'. In addition, the slowdown in growth of the Chinese economy is raising concerns among firms in Southeast Asia. This is because China has been seen as the biggest market for the firms, whereas the United States and Europe are regarded as 'innovative economies' with 'no purchasing power'. Finally, the recent agreement to establish the ASEAN Economic Community is seen as a threat, especially by local smaller firms. These suspect that the AEC will benefit only the large multinationals able to exploit the advantages offered by the larger market. However, one exception to the gloomy regional outlook appears to be the Philippines, which has managed to turn into a higher economic growth path and to start an active campaign to root out corruption in the society.

\section{Impact of Regional Economic Integration}

Eden et al. (2005) point out that regional agreements foster regulatory convergence among member countries, which offers protection and bargaining power to MNCs. Thus regional trade agreements are a constraint for the host country. However, access to regional markets can also be seen as a power resource of the host country. It is argued here that this is the case for developing country groupings, such as ASEAN. These groupings have liberalized regional trade but regional convergence is still not in place, as the free trade agreement is not binding for the governments (Severino 2008: 252). However, AFTA and other regional policies basically support FDI in global industries with regional pro- 
duction networks, similar to other free trade areas and customs unions that have recently spurred reforms in their member countries (World Bank 2010, 2013). This can be regarded as a resource, not a constraint, for the host country.

As was seen in the World Bank's Doing Business indicators, the four selected ASEAN countries perform relatively well when it comes to trading across borders (Table 2). This demonstrates the importance of foreign trade for the countries and the improvements achieved in this respect through national and regional efforts. Since 2004, ASEAN has been working on the so-called 'single window' to enable exporters and importers to submit all trade documents (e.g. customs declarations, certificates of origin) at a single location (UN 2012). The aim is to develop both national single windows and an ASEAN-wide single window that would entail an exchange of electronic customs declarations among member countries and an integration of members' national single windows so that a single submission of information would suffice for all ASEAN countries (ibid., World Bank 2013). According to an interviewee at a European Union Chamber of Commerce and Industry, as of 2015, the single window was not yet working. In contrast, some progress had been made in terms of ASEAN customs cooperation, although this is also expected to take time.

The steps taken in ASEAN-wide cooperation indicate that firms should regard integration as beneficial for their operations. However, existing research suggests that relatively few firms (only about 30 per cent) use the preferences offered by the Asian FTAs and thus benefit from the lower tariffs (Kawai and Wignaraja 2011a). The main impediments to the use of FTA preferences are lack of information, delays and costs related to administrative procedures, and small preference margins (ibid.). However, the present study shows an even smaller impact of regional economic integration. Interviews suggest that the ASEAN free trade area does not have much effect on the business of the firms. Seven respondents see regional integration having 'no impact whatsoever' on their operations. The most expressive is the manager of a smaller firm, who commented that the possible developments in integration would have 'diddly-squat' significance for their operations. Only two respondents mention that the reductions in AFTA tariffs should ease the businesses in general. The rest of the companies - four - are more neutral, answering either 'not much' or being unsure whether or not AFTA had any effect. While it seems that the lack of information is the most obvious reason for the general ignorance about ASEAN integra- 
tion, it is still surprising that none of the firms perceive a benefit from the free trade area.

Three explanations can be traced for the lack of AFTA impact on the studied firms as well as their ambivalence on regional integration:

- the slowness of ASEAN regional economic integration,

- the lack of ASEAN-wide regional production chains of the studied firms,

- the industry base of the Finnish firms operating in Southeast Asia.

First, the generally slow pace of regional economic integration in Southeast Asia is reflected in the firms' views. Most respondents had observed formal declarations, 'lines of limousines, and joint seminars', but did not see many concrete results 'in these twenty years'. They recognize that ASEAN integration has more effect on the 'political side, reducing the intra-regional combats and conflicts'. In contrast, economic integration remains obscure, as the changes in the tariff regimes have been slow and thus not discernible for the firms. For firms, it is hard to build strategies for dealing with a free trade area that is only in the making, because the possible advantages - 'if there are any' - would be realized only afterwards. This indicates that company strategies are based on the country-specific advantages of the host countries, not regional ones. Echoing recent findings on European firms' lack of a regional strategy in ASEAN (EU-ABC 2015), none of the subsidiaries studied here report having an 'ASEAN strategy'. Instead, their investments are based on location-bound resources of the host country (Eden et al. 2005: 270) that are tied with the firms' global strategies where the EU and China have a central role.

Second, contrary to many other MNCs, the interviewed firms do not typically operate regional production networks in Southeast Asia. Instead, most of the Finnish subsidiaries are serving the domestic host country market. The business functions and market areas were analyzed for 15 units of the 13 interviewed firms for this study (Figure 2.). Of the 15 units, altogether 13 are selling for the local market either by sales/services or production in the host country. Many of them engage in foreign trade only by importing from the European Union and/or China: five companies import from Finland, two from other European Union countries, and two from China, to their ASEAN units. This resonates with an earlier finding of Finnish investments in Malaysia having a larger impact on Finland's exports to Malaysia than the other way around (Kettunen 2007). In comparison, intra-regional trade is relatively small among the firms. Only four of the subsidiaries engage in intra-ASEAN trade: 
one company exports from Malaysia to Singapore, one from Malaysia to larger Southeast Asia, one imports from Malaysia and Indonesia to Singapore, and one from Singapore to Indonesia. Similar indications were given by Mirza and Giroud (2004: 236), who found that only seven per cent of 113 firms were selling to the ASEAN market outside of the host country. Also, it is relatively rare for the studied Finnish companies to use Southeast Asia as a production platform for exporting to third countries. Only one company exports from its Southeast Asian unit to China, and one to the United States. Overall, the firms seem to represent a case within the broader European businesses in Southeast Asia: while the European Union is the biggest source of inward FDI in ASEAN (e.g. Kawai 2016: 10), European firms mainly invest in the region to serve host country customers (EU-ABC 2015: 14).

Third, the industry base of the internationalized Finnish firms is different from those that are typical in Southeast Asian regional production networks, such as electronics, automobiles or palm oil (ASEAN 2014: xxi). Most of the Finnish subsidiaries in ASEAN countries, and elsewhere in Asia, are in information technology (such as software), as well as in different industries within the forest-based sector, such as pulp and paper, engineering, machinery manufacture and related services (cf. Kettunen 2007). Many of these industries can be characterized as

FIGURE 2. Business Functions and Market Areas of the Interviewed Subsidiaries (number of units)

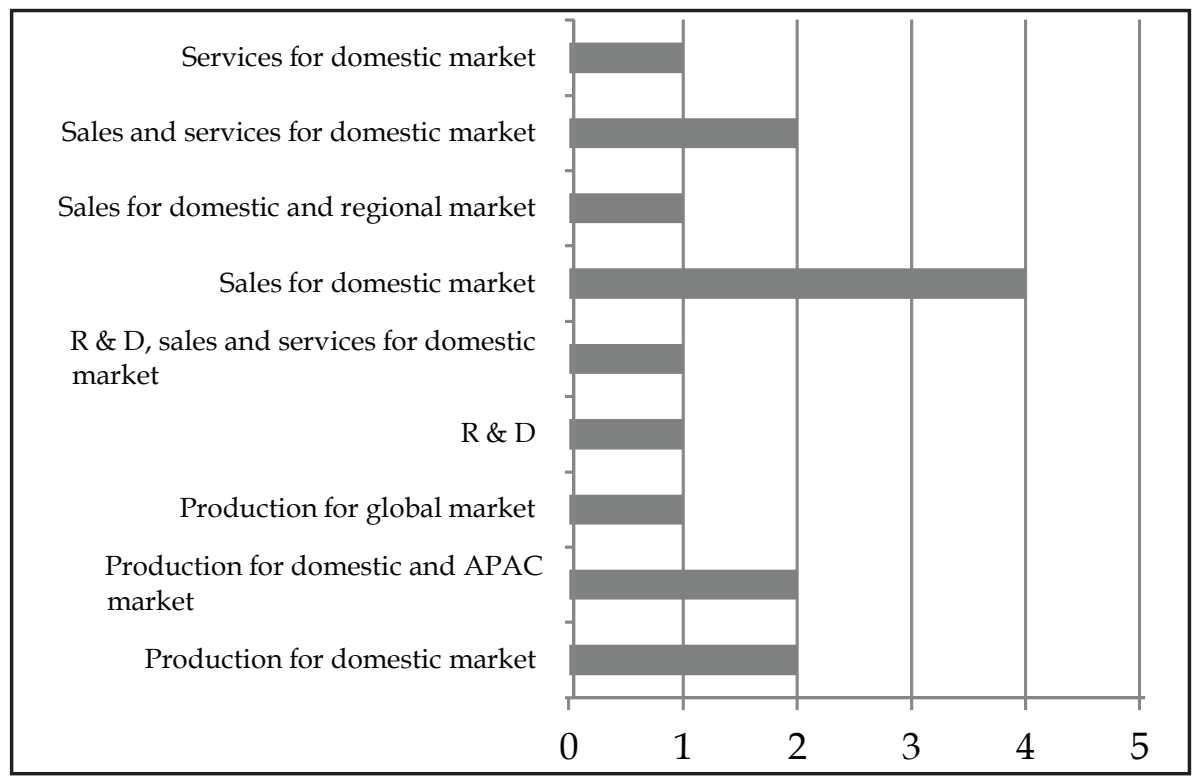

Source. Interviews 
global, with production networks extending between several continents (WTO 2011: 12, 23).

\section{Conclusion}

Southeast Asia, consisting of several export-oriented economies at various stages of economic development and striving for regional integration, provides an interesting platform from which to examine firm-state relations. This article has considered the MNC-host government bargaining relationship in the specific case of Finnish firms operating in ASEAN countries. The focus has been on the firms' experiences of host country policies, both national and regional, and the possible institutional constraints that the firms encounter in the bargain. The article adds to the existing research by combining theorization of MNC-host government bargaining relationships (e.g. Eden et al. 2005, Kobrin 1987, Stopford et al. 1991) with that of regional economic integration, particularly the literature on business response to Asian FTAs (Kawai and Wignaraja 2011a, 2013), as well as the institutional approach (North 1990, Peng 2003, Peng et al. 2008).

Drawing from the interview data, it is argued that formal and informal institutions pose constraints for foreign firms in bargaining with host country governments. Informal institutions that require tacit knowledge, such as unwritten social norms and local practices, may be particularly difficult for the firms to cope with, thus affecting their bargaining power. Informal institutions are rooted in the local culture, and being persistent, they pose additional constraints for the firms in their relations with the host state. International financial crises further complicate the bargaining by obliging the governments to take measures to protect the domestic economy that often adversely affect foreign firms (e.g. through increased trade barriers or tightened immigration procedures). In addition, contrary to Eden et al. (2005), regional agreements among developing countries, such as ASEAN, do not necessarily pose a constraint for the host country. This is because of the lack of regulatory convergence between the participating countries, since the agreements (such as AFTA) are typically non-binding and include numerous national exceptions to the free trade rule. Instead, such agreements may serve as power resources for the host countries, as they offer trade possibilities for the firms.

Empirically, it is found that the degree of institutional constraint varies considerably depending on the host country in question. The 
firms perceive the regulatory environments of the four selected ASEAN economies (Singapore, Malaysia, Thailand and Indonesia) to vary from easy to difficult, with different levels of bureaucracy, trade barriers, and promotion or restrictions on inward FDI. This aligns with the World Bank's Doing Business indicators that assess the regulatory environment of the countries with regard to the ease of doing business. In addition, it is found that company size and operation mode figure in whether firms build personal relationships with the host governments; smaller firms and those with only sales offices are less likely to do so. The global financial crisis in 2008 somewhat affected the firms' relationships with the public sector by tightening some regulations, notably in the form of increased trade barriers and stricter immigration procedures. Thus, the crisis made the regulatory environment more challenging through changes in both formal and informal institutions (cf. North 1990).

Also, the investment drivers of the firms seem to mirror many of the European businesses in the region. While the Southeast Asian countries are active in regional economic integration through two regional initiatives, AFTA and the recently agreed ASEAN Economic Community, these barely have any effect on the firms' strategies. This is explained by the slowness of ASEAN integration, the lack of intra-regional production networks of the studied firms, and the industry base of the internationalized Finnish firms in general. In contrast to the regional production networks typical for many Japanese or US firms, the main investment motive of the studied Finnish companies is to serve the local host country market by importing or manufacturing products or operating in the services sector.

Erja Kettunen is Adjunct Professor of Economic Geography at Turku School of Economics, University of Turku, Finland; and Research Manager, Aalto University School of Business, Helsinki, Finland. Email: erja.kettunen-matilainen@utu.fi

\section{NOTES}

1 I wish to thank the anonymous referee for constructive comments, as well as Claes G. Alvstam for valuable insights on earlier versions of the article. Funding from the Finnish Foundation for Economic Education is gratefully acknowledged.

2 Data tables on GDP growth (annual \%). Washington, DC: The World Bank. http:/ / data. worldbank.org/indicator/NY.GDP.MKTP.KD.ZG?page=1. Accessed 13 October 2016.

3 ASEAN Economic Community. Jakarta: ASEAN Secretariat. http://asean.org/asean- 
economic-community/. Accessed 13 October 2016.

4 ASEAN Free Trade Area (AFTA Council). Jakarta: ASEAN Secretariat. http://asean. org/asean-economic-community/asean-free-trade-area-afta-council/. Accessed 13 October 2016.

5 These numbers are proportional to the total number of Finnish subsidiaries in the region. There are, approx., 70 Finnish firms in Singapore, 50 in Malaysia, 20 in Indonesia, 40 in Thailand, and 25 in the Philippines, according to the Embassies of Finland in the respective countries (http:/ / www.formin.fi). Since each interview typically touched several of the firm's units, the sample, while being small, reflects the industrial base and the geographical distribution of Finnish firms in the region.

\section{REFERENCES}

Alvstam, Claes G., Harald Dolles, and Patrik Ström (eds.) 2014. Asian Inward and Outward FDI. New Challenges in the Global Economy. Basingstoke: Palgrave Macmillan.

ASEAN 2014. ASEAN Investment Report 2013-2014: FDI Development and Regional Value Chains. Jakarta: ASEAN Secretariat \& United Nations Conference on Trade and Development.

Athukorala, Prema-chandra 2007. Multinational Enterprises in Asian Development. Cheltenham: Edward Elgar.

Basu Das, Sanchita (ed.) 2012. Achieving the ASEAN Economic Community 2015. Challenges for Member Countries \& Businesses. Singapore: ISEAS.

Chin, Yee Whah 2012. 'The Evolution of Malaysia's Development Strategies and the Global Economy: Responses from SMEs and Civil Societies'. Copenhagen Journal of Asian Studies 30 (1): 11-35.

Coxhead, Ian 2015. Introduction: Southeast Asia's long transition. In I. Coxhead (ed.) Routledge Handbook of Southeast Asian Economics. New York: Routledge 2015: 3-20.

Dunning, John H. 1998. 'Location and the Multinational Enterprise: A Neglected Factor?' Journal of International Business Studies, 29 (1): 45-66.

Eden, Lorraine, Stefanie Lenway, and Douglas A. Schuler 2005. From the Obsolescing Bargain to the Political Bargaining Model. In R. Grosse (ed.) International Business and Government Relations in the 21st Century, Cambridge: Cambridge University Press 2005: 251-271.

EU-ABC 2015. EU-ASEAN business sentiment survey 2015. Singapore: EU-ASEAN Business Council.

Fujita, Masahisa, Ikuo Kuroiwa, and Satoru Kumagai (eds.) 2011. The Economics of East Asian Integration: A Comprehensive Introduction to Regional Issues. Cheltenham: Edward Elgar.

Grosse, Robert 2005.,Introduction. In R. Grosse (ed.) International Business and Government Relations in the 21st Century, Cambridge: Cambridge University Press. 2005: 3-22.

Grosse, Robert, and Jack N. Behrman 1992. 'Theory in international business'. Transnational Corporations, 1 (1): 93-126.

Gugler, Philippe, and Julien Chaisse (eds.) 2010. Competitiveness of the ASEAN Countries. Corporate and Regulatory Drivers. Cheltenham: Edward Elgar.

Hew, Denis (ed.) 2007. Brick by Brick: The Building of an ASEAN Economic Community. Singapore: Institute of Southeast Asian Studies.

Holmes, R. Michael, Toyah Miller, Michael A. Hitt and M. Paz Salmador 2013. 'The Interrelationships Among Informal Institutions, Formal Institutions, and Inward Foreign Direct Investment.' Journal of Management 39 (2): 531-566. 
Kawai, Masahiro 2016. 'Challenges for the ASEAN Economic Community and ASEANJapan Relations.' In M. Kawai, M. Thuzar and B. Hayton (eds.) ASEAN's Regional Role and Relations with Japan. The Challenges of Deeper Integration. Research Paper. London: Chatham House, the Royal Institute of International Affairs.

Kawai, Masahiro, and Ganeshan Wignaraja 2008. 'EAFTA or CEPEA. Which Way Forward?' ASEAN Economic Bulletin 25 (2): 113-139.

Kawai, Masahiro, and Ganeshan Wignaraja 2009. 'The Asian "Noodle Bowl”: Is it serious for business?' ADBI Working Paper 136. Tokyo: Asian Development Bank Institute.

Kawai, Masahiro, and Ganeshan Wignaraja 2011a. Main findings and policy implications. In M. Kawai and G. Wignaraja (eds.) Asia's Free Trade Agreements. How is Business Responding? Asian Development Bank and ADB Institute. Edward Elgar Publishing.

Kawai, Masahiro, and Ganeshan Wignaraja 2011b. 'Asian FTAs: Trends, prospects and challenges'. Journal of Asian Economics 22 (1): 1-22.

Kawai, Masahiro, and Ganeshan Wignaraja 2013. 'Patterns of Free Trade Areas in Asia'. Policy Studies, No. 65. Honolulu: East-West Center.

Kee, Hiau Looi, Cristina Neagu, and Alessandro Nicita 2013. 'Protectionism on the rise? Assessing national trade policies during the crisis of 2008. The Review of Economics and Statistics, 95 (1): 342-346.

Kettunen, Erja 2007. Inward direct investments in ASEAN: The case of Finnish investments and trade in Malaysia. In B. Andreosso-O'Callaghan, J.P. Bassino, S. Dzever, and J. Jassaud (eds.) The Economic Relations between Asia and Europe: Organizations, Trade and Investment. Oxford: Chandos Publishing 2007: 45-63.

Kobrin, Stephen J. 1987. 'Testing the bargaining hypothesis in the manufacturing sector in developing countries'. International Organization, 41 (4): 609-638.

Kuroiwa, Ikuo, and Mun Heng Toh (eds.) 2008. Production networks and industrial clusters: Integrating economies in Southeast Asia. Singapore: IDE-JETRO \& ISEAS.

Kuroiwa, Ikuo, and Satoru Kumagai 2011. A history of de facto economic integration in East Asia. In Fujita, M., I. Kuroiwa and S. Kumagai (eds.) The Economics of East Asian Integration: A Comprehensive Introduction to Regional Issues. Cheltenham: Edward Elgar 2011: 15-50.

Lee, Yoong Yoong (ed.) 2011. ASEAN matters! Reflecting on the Association of Southeast Asian Nations. Hackensack: World Scientific.

Luo, Yadong 2001. 'Toward a Cooperative View of MNC-Host Government Relations: Building Blocks and Performance Implications'. Journal of International Business Studies, 32 (3): 401-419.

Luo, Yadong 2005. 'Shifts of Chinese government policies on inbound foreign direct investment'. In R. Grosse (ed.) International Business and Government Relations in the 21st Century, Cambridge: Cambridge University Press 2005: 291-313.

Makkonen, Hannu, Mikko Pohjola, Rami Olkkonen and Aki Koponen 2014. 'Dynamic capabilities and firm performance in a financial crisis'. Journal of Business Research, 67 (1): 2707-2719.

Meyer, Klaus E. 2004. Perspectives on multinational enterprises in emerging economies. Journal of International Business Studies, 35 (4): 259-276.

Mirza, Hafiz and Axèle Giroud 2004. 'Regionalization, foreign direct investment and poverty reduction. Lessons from Vietnam in ASEAN. Journal of the Asia Pacific Economy, 9 (4): 223-248.

Nidhiprabha, Bhanupong 2015. 'The global financial crisis and macroeconomic policy in Southeast Asia'. In I. Coxhead (ed.) Routledge Handbook of Southeast Asian Economics. New York: Routledge 2015: 385-407.

Nishikimi, Koji, and Ikuo Kuroiwa 2011. 'Analytical framework for East Asian integration (1): industrial agglomeration and concentrated dispersion'. In Fujita, M., I. 
Kuroiwa and S. Kumagai (eds.) The Economics of East Asian Integration: A Comprehensive Introduction to Regional Issues. Cheltenham: Edward Elgar 2011: 385-405.

North, Douglass 1990. Institutions, Institutional Change and Economic Performance. Cambridge: Cambridge University Press.

Peng, Mike W. 2003. 'Institutional Transitions and Strategic Choices'. Academy of Management Review 28 (2): 275-296.

Peng Mike W., Denis Y. L. Wang, and Yi Jiang 2008. 'An institution-based view of international business strategy: a focus on emerging economies'. Journal of International Business Studies 39 (5): 920-936.

Risager, Ole 2013. 'Adjusting to the Financial Crisis: How Emerging Markets and Developing Economies have Fared'. Copenhagen Journal of Asian Studies 31 (2): 79-105.

Strange, Susan 1988. States and markets. $2^{\text {nd }}$ Ed. London, UK: Continuum.

Stopford, John M., and Susan Strange with John S. Henley 1991. Rival states, rival firms. Competition for world market shares. Cambridge: Cambridge University Press.

Teh, Benny Cheng Guan 2015. 'Region Construction: The Dynamics of Cross-Level Networking in East Asia'. Copenhagen Journal of Asian Studies 33 (2): 12-37.

UN 2012. Single Window Planning and Implementation Guide. United Nations ESCAP and UNECE. New York and Geneva: United Nations.

UNCTAD-JETRO 2008. South-South Trade in Asia: The Role of Regional Trade Agreements. Geneva and Tokyo: United Nations Conference on Trade and Development and Japan External Trade Organization.

Vernon, Raymond 1971. Sovereignty at Bay: The Multinational Spread of U.S. Enterprises. New York: Basic Books.

Vernon, Raymond 1977. Storm Over the Multinationals: The Real Issues. Cambridge, Mass.: Harvard University Press.

Wagner, Sigrun M. 2013. 'Why Do MNEs Engage in MNE-Government Relations? Empirical Evidence from the European Union and the Automotive Industry'. In G. Cook and J. Johns (eds.) The Changing Geography of International Business. Basingstoke, U.K.: Palgrave Macmillan 2013: 54-76.

World Bank 2007. Doing Business 2008. Washington, DC: World Bank Group.

World Bank 2010. Doing Business 2011: Making a Difference for Entrepreneurs. Washington, DC: World Bank Group.

World Bank 2014. Doing Business 2015: Going Beyond Efficiency. Washington, DC: World Bank Group.

WTO 2011. Trade patterns and global value chains in East Asia: From trade in goods to trade in tasks. Geneva: IDE-JETRO \& World Trade Organization. 
Erja Kettunen

\section{APPENDIX}

TABLE A1. The number of interviewed managers by the industry and size of the parent company

\begin{tabular}{|l|c|c|}
\hline & $\begin{array}{l}\text { Up to 2.000 } \\
\text { employees }\end{array}$ & $\begin{array}{l}\text { Over 2.000 } \\
\text { employees }\end{array}$ \\
\hline Information technology \& Electronics & 4 & - \\
\hline Forest-based industries \& Chemistry & - & 4 \\
\hline Engineering & - & 2 \\
\hline Other industries & 1 & 1 \\
\hline Services and support organizations & 5 & 1 \\
\hline Total & 10 & 8 \\
\hline
\end{tabular}

Source: Interviews 